\title{
Technology acceptance model of student ability and tendency classification system
}

\author{
Mardian Dwi Jaelani 1,*, Aji Prasetya Wibawa ${ }^{2}$, Utomo Pujianto ${ }^{3}$ \\ Department of Electrical Engineering, State University of Malang, Malang, Indonesia \\ ${ }^{1}$ dwimardianstudent@gmail.com *; ${ }^{2}$ aji.prasetya.ft@um.ac.id; ${ }^{3}$ utomo.pujianto.ft@um.ac.id \\ * corresponding author
}

\begin{tabular}{|c|c|}
\hline ARTICLE INFO & ABSTRACT \\
\hline $\begin{array}{l}\text { Article history } \\
\text { Received August 18, } 2018 \\
\text { Revised September 14, } 2018 \\
\text { Accepted October 1, } 2018 \\
\text { Keywords } \\
\text { TAM } \\
\text { Ability } \\
\text { Tendency } \\
\text { Student } \\
\text { Classification system }\end{array}$ & $\begin{array}{l}\text { Skill and competency test (SCT) is part of the Government's intervention in } \\
\text { ensuring the quality of education in the Vocational High School (SMK) } \\
\text { education unit. The teacher prepares vocational students to face SCT, } \\
\text { especially vocational students of class XII. However, the obstacles often } \\
\text { encountered by teachers in recommending students to choose competency that } \\
\text { are in accordance with students' abilities. Ability Classification System and } \\
\text { Student Ability Trends by applying the Learning Vector Quantization (LVQ) } \\
\text { algorithm, it can be used as a solution to assist teachers in classifying student } \\
\text { abilities and the tendency of students' abilities to be used to select skills } \\
\text { competencies during SCT. This study aims to examine the use of the } \\
\text { technology acceptance model (TAM) implementation of the classification } \\
\text { system. As a result, the average user has felt the usefulness and ease of use of } \\
\text { the system. Each TAM variable has a significant effect. }\end{array}$ \\
\hline
\end{tabular}

This is an open access article under the CC-BY-SA license.

\section{Introduction}

The teacher prepares Vocational students to be able to choose the competency skills of students in facing the Expertise Competency Test. The obstacles that are often encountered are (1) the teacher has difficulty in classifying the ability of students (2) the teacher has difficulty in recommending students to choose the Skills Competency Test package that is in accordance with the tendency of students' abilities. The student's ability in question is Desktop Programming, Web Programming, and Mobile Device Programming. Therefore we need a mechanism or system that can help teachers in preparing vocational students to face the Expertise Competency Test which aims to recommend students to choose the Skills Competency Test package according to their ability tendency and to know the level of student learning outcomes as long as students learn five semester skills students based on student grades. One of them is by using a Decision Support System (DSS).

Decision Support System (DSS) is a computer-based interactive system that is able to help decision makers in determining a choice [1]. This DSS uses the Learning Vector Quantization (LVQ) algorithm to solve the problem of classifying student abilities and the tendency of students to choose the SCT package. Some examples of problems that use the LVQ algorithm include classification to select OSN participant students [2], academic value prediction [3]. So that by applying the Learning Vector Quantization algorithm, it is hoped that it can help the process of classifying students' abilities appropriately and the system can be useful and an easy system for user use.

But in reality, many implementations of failed systems are caused not by technical factors but rather by user factors [4]. The factors that influence people to use the system are extrinsic motivation and intrinsic motivation [5]. In this research, intrinsic motivation obtained from perceived ease of use, while extrinsic motivation obtained from perceived usefulness. In this study intrinsic motivation was obtained from perceived ease of use, while extrinsic motivation was obtained from perceived 
usefulness. TAM illustrates that the use of the system will be influenced by usefulness variables and ease of use variables [6].

This study examines the behavior of users of the classification system of students' abilities using the LVQ algorithm based on the factors that influence it with the Technology Acceptance Model (TAM) approach [6]. The purpose of this study is to find out (1) the effect of perceived Ease of Use (PEOU) on Perceived Usefulness (PU), (2) Knowing the influence of Perceived Ease of Use (PEOU) and Perceived Usefulness (PU) on Attitude Toward Using (ATU), (3) Knowing the influence of Perceived Usefulness (PU) and Attitude Toward Using (ATU) on Behavioral Intention to Use (ITU), and (4) Knowing the effect of Behavioral Intention to Use (ITU) on Actual System Usage (ASU).

\section{Method}

The Student Ability and Tendency Classification System (SATCS) is a decision-making system using the LVQ algorithm to help teachers classify students' abilities and the tendency of students to choose SCT packages that match students' abilities. Figure 1 shows the use case diagram. Based on Figure 1 can be explained, there are 2 users, namely (1) Students and (2) Teachers. Before using SATCS students must register in advance to obtain access rights. Meanwhile, the admin must log in first to be able to use the system.

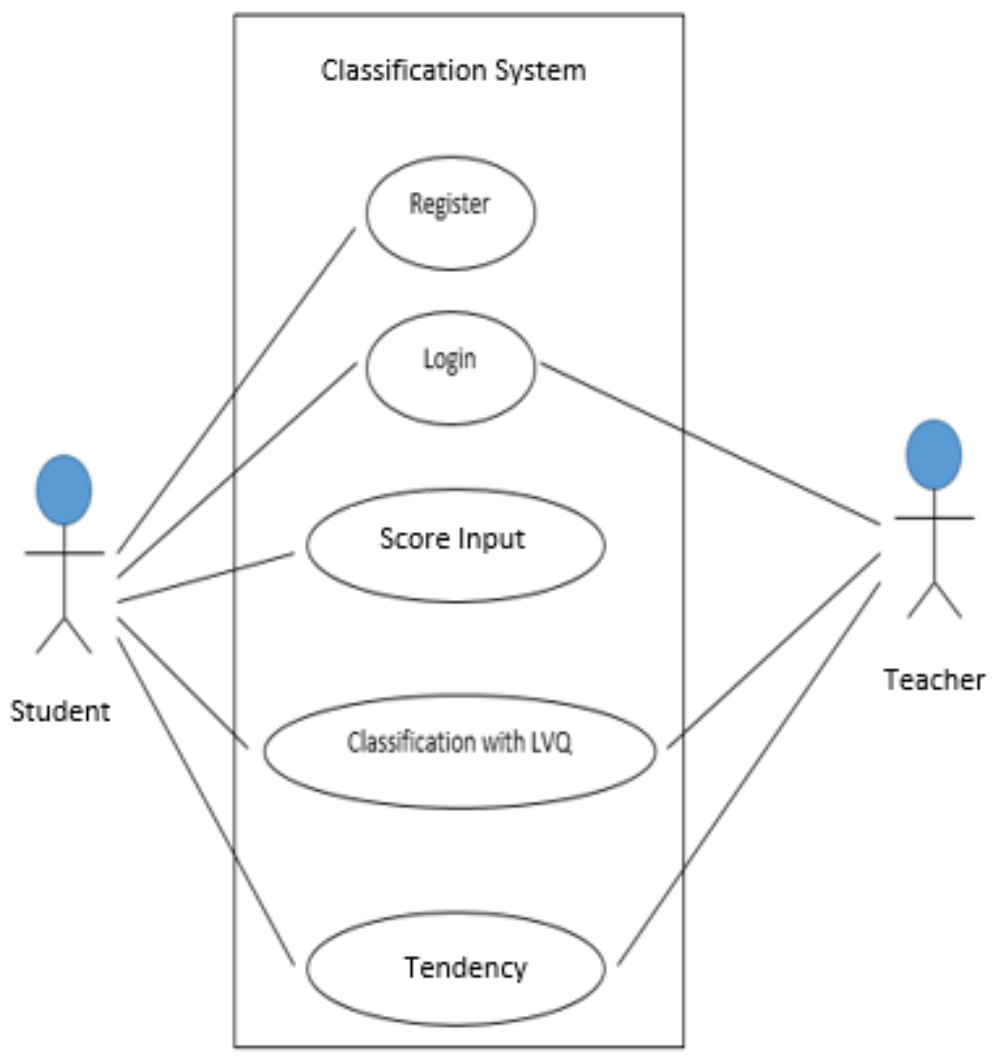

Fig. 1.Use case diagram SATCS.

After inputting the values in each subject, the system will perform calculations using LVQ. The calculation results will provide a classification of students' abilities. The range of ratings is shown in Table 1.

Table 1. Range of ratings

\begin{tabular}{cc}
\hline Average value interval & Classification \\
\hline 78 to $<=82$ & Good Enough \\
\hline$>82$ to $<=88$ & Satisfy \\
\hline$>88$ to 100 & Very Satisfactory \\
\hline
\end{tabular}


Figure 2 shows the results of the classification of students' abilities. The results of the classification will be processed to get the tendency of students' abilities. The results of the tendency can be used by students to choose a SCT package that is in accordance with students' abilities.

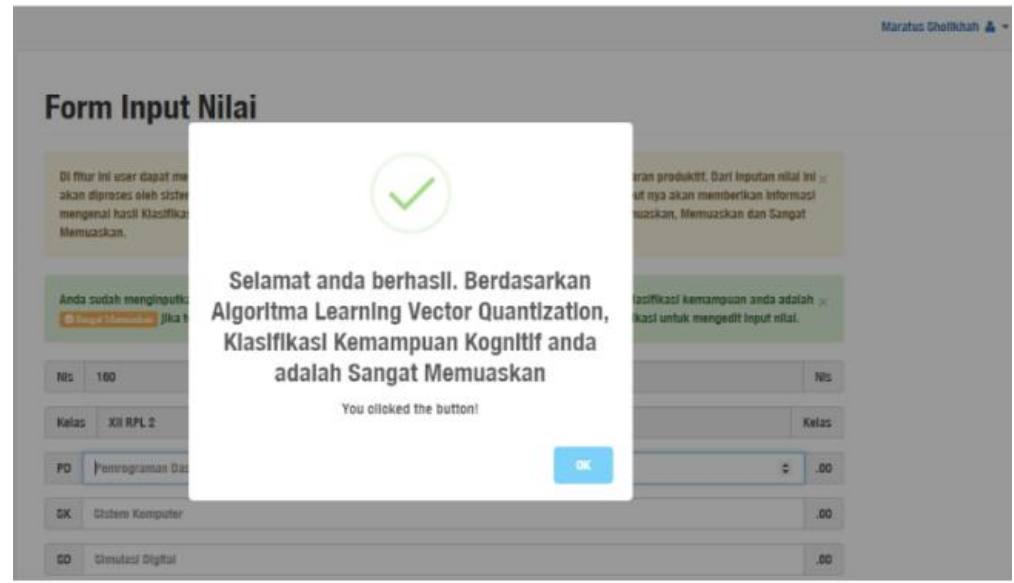

Fig. 2.Student Ability Classification Page

Analysis of user behavior is done by using the TAM instrument as an approach to data collection combined with a linear regression model as a data analysis approach to test the relationship between the main variables TAM [4], [7]-[9]. The description of the framework for using TAM can be explained in Figure 3.

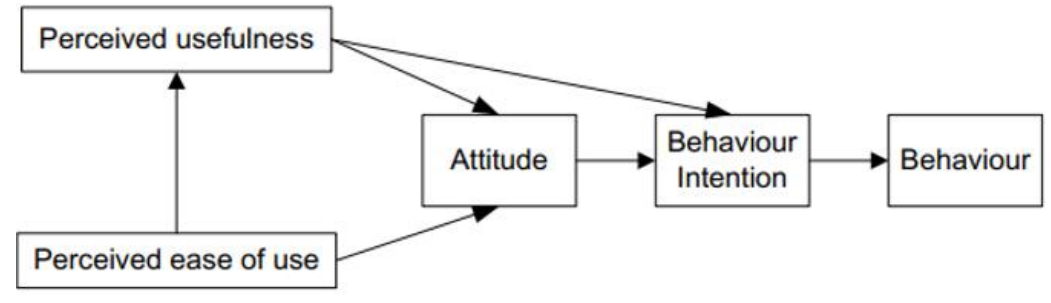

Fig. 3.TAM usage framework [6]

TAM instrument indicators were adopted from previous studies that have been carried out [4], [6]. The type of data obtained is quantitative data. Quantitative data is data in the form of questionnaires. This data is obtained from the results of questionnaires given to respondents. The questionnaire used is a closed questionnaire, namely the questionnaire that has been provided with the answer option so that the respondent just has to choose the appropriate answer by simply checking the answer columns provided. The scale used in the form of Likert scale (likert scale) 4 categories namely (SS) Strongly agree, (S) Agree, (TS) Disagree, and (STS) Strongly disagree [10].

The validity test used is the product of the Pearson Correlation moment which uses the principle of correlating or connecting between each item score with the total score obtained in the study. [7]. Reliability testing is also used to measure the level of consistency of a person's answer to the statement used. Reliability test using Cronbach alpha $(\alpha)$ statistical test [11]. Validity and reliability test calculations use IBM SPSS Statistic Base 23.0. Linear regression analysis is used as a tool for analyzing and interpreting data. Moreover, linear regression analysis is also used to test the hypothesis [10]. This analysis aims to prove the existence or absence of a function relationship between two or more independent variables and one dependent variable.

Relationship of Perceived Ease of Use (PEOU) to Perceived Usefulness (PU). Hypothesis testing uses simple linear regression analysis with $t$ test and with significance level of 0.05 and 2 sides. The first hypothesis is

- $H_{a}=$ There is a positive and significant relationship between Perceived Ease of Use (PEOU) to Perceived Usefulness (PU) 
- $H_{0}=$ There is no positive and significant relationship between Perceived Ease Of Use (PEOU) to Perceived Usefulness (PU)

Relationship of Perceived Ease Of Use (PEOU) and Perceived Usefulness (PU) to Attitude Toward Using (ATU). Testing the hypothesis using multiple linear regression analysis with $F$ test with a significance level of 0.05 with df 1 (number of variables -1) and df 2 (n-k-1) (n is the amount of data and $\mathrm{k}$ is the number of independent variables). The second hypothesis is

- $H_{a}=$ There is a positive and significant relationship between Perceived Ease of Use (PEOU) and Perceived Usefulness (PU) to Attitude toward Using (ATU).

- $H_{0}=$ There is no positive and significant relationship between Perceived Ease of Use (PEOU) and Perceived Usefulness (PU) to Attitude toward Using (ATU).

Relationship of Perceived Usefulness (PU) and Attitude Toward Using (ATU) to Behavioral Intention Of Use (ITU). Testing the hypothesis using multiple linear regression analysis with $\mathrm{F}$ test with a significance level of 0.05 with df 1 (number of variables -1) and df 2 (n-k-1) (n is the amount of data and $\mathrm{k}$ is the number of independent variables). The third hypothesis is

- $H_{a}=$ There is a positive and significant relationship between Perceived Usefulness (PU) and Attitude Toward Using (ATU) to Behavioral Intention of Use (ITU)

- $H_{0}=$ There is no positive and significant relationship between Perceived Usefulness (PU) and Attitude Toward Using (ATU) to Behavioral Intention of Use (ITU)

Relationship of Behavioral Intention Of Use (ITU) to Actual System Use (ASU). Hypothesis testing uses simple linear regression analysis with a t test with significance level of 0.05 and 2 sides. The fourth hypothesis is

- $H_{a}=$ There is a positive and significant relationship between Behavioral Intention of Use (ITU) to Actual System Use (ASU).

- $H_{0}=$ There is no positive and significant relationship between Behavioral Intention of Use (ITU) to Actual System Use (ASU).

\section{Result and Discussion}

Based on questionnaire questionnaires that have been carried out the respondent characteristics that contribute to the research can be seen in Table 2 .

Table 2.

Demographic Analysis

\begin{tabular}{ccccc}
\hline Status & Frequency & Percent & Valid Percent & Cumulative Percent \\
\hline Student & 58 & 98.3 & 98.3 & 98.3 \\
\hline Teacher & 1 & 1.7 & 1.7 & 100.0 \\
\hline Total & 59 & 100.0 & 100.0 & \\
\hline
\end{tabular}

Reliability analysis is done using the help of IBM SPSS $\mathrm{v} 23$. Table 3 shows the results of the reliability testing of the TAM instrument obtained by cronbach alpha $(\alpha)$ of 0.862 . Because the Cronbach alpha score is above 0.8 , the instrument can be said to be a reliable measurement instrument and the instrument is declared valid [8]-[10].

Table 3.

Reliability Test Result

\begin{tabular}{cc}
\hline Cronbach's Alpha & N of Items \\
\hline, 862 & 25 \\
\hline
\end{tabular}

The TAM instrument used in the Perceived Usefulness (PU) variable has 6 indicators, the Variable Perceived Ease of Use (PEOU) there are 8 indicators, Attitude toward Using (ATU) there are 3 indicators, the Behavioral Intention to Use (ITU) variable has 4 indicators, and the Actual System Use (ASU) variable has 4 indicators. Table 4 shows the results of the TAM instruments by students 
Table 4.

Students’ TAM Instrument Result

\begin{tabular}{ccccccc}
\hline No & Variable & Resp $(\mathbf{N})$ & $\mathbf{N}$ & Total Respon & Average Respon & Std. Deviation \\
\hline 1. & PU & 58 & 6 & 1135 & 19.59 & 2.185 \\
\hline 2. & PEOU & 58 & 8 & 1534 & 26.41 & 2.534 \\
\hline 3. & ATU & 58 & 3 & 563 & 9.71 & 1.601 \\
\hline 4. & ITU & 58 & 4 & 718 & 12.40 & 1.611 \\
\hline 5. & ASU & 58 & 4 & 685 & 11.81 & 1.670 \\
\hline
\end{tabular}

The results of the TAM instrument are then used to categorize the level of the level criteria of the TAM variables. The formula used to calculate interval classes is as follows:

$$
\text { Interval class length }=\frac{\text { Biggest Score }- \text { Smallest Score }}{\text { Amount of interval classes }}
$$

After this step, then proceed with percentagen in the following formula. Where $\mathrm{P}$ stands for Percentage of frequency distribution, F stands for Frequency (Number of Respondents to answer), and $\mathrm{N}$ stands for Total number of respondents.

$$
P=\frac{P}{N} \times 100 \%
$$

\subsection{Result of Students' Descriptive Analysis}

Based on formulas 1 and 2, the results of the calculation of PU variable criteria are shown in Table 5. Table 5 shows that 58 students were the subjects of the study, 33 students $(56.9 \%)$ answered that the Student Ability Classification system was very useful, 24 students (41.4\%) answered that the Student Capability Classification system was useful, 1 student $(1.7 \%)$ answered that the Student Ability Classification system was less useful, and 0 students (0\%) answered that the Student Ability Classification system was not useful. The average respondent answers in a very useful and useful range.

Table 5. The frequency variable of PU criteria.

\begin{tabular}{ccccc}
\hline No & Interval & criteria & Frequency (f) & Persentage (\%) \\
\hline 1. & $19,5-24$ & Very Useful & 33 & $56,9 \%$ \\
\hline 2. & $14,9-19,4$ & Useful & 24 & $41,4 \%$ \\
\hline 3. & $10,3-14,8$ & Less Usefull & 1 & $1,7 \%$ \\
\hline 4. & $6-10,2$ & Not Useful & 0 & $0 \%$ \\
\hline \multicolumn{7}{r}{ Total } & & 58 & $100 \%$ \\
\hline
\end{tabular}

Table 6 shows that 58 students were the subjects of the study, 29 students (50\%) answered that the Student Ability Classification system was very easy, 28 students $(48.3 \%)$ answered that the Student Ability Classification system was easy, 1 student (1.7\%) answered that the Student Ability Classification system was less easy, and 0 students (0\%) answered that the Student Ability Classification system was not easy. The average respondent answers in a very easy and easy range.

Table 6. The frequency variable of PEOU criteria

\begin{tabular}{ccccc}
\hline No & Interval & Criteria & $\begin{array}{c}\text { Frequency } \\
(\mathbf{f})\end{array}$ & $\begin{array}{c}\text { Persentage } \\
(\boldsymbol{\%})\end{array}$ \\
\hline 1. & $27-32$ & $\begin{array}{c}\text { Very } \\
\text { Easy }\end{array}$ & 29 & $50 \%$ \\
\hline 2. & $21-26$ & Easy & 28 & $48,3 \%$ \\
\hline 3. & $15-20$ & Less & 1 & $1,7 \%$ \\
\hline 4. & $8-14$ & Easy & & $0 \%$ \\
\hline & Total Easy & 0 & $100 \%$ \\
\hline
\end{tabular}


Table 7 shows that 58 students were the subjects of the study, 32 students (52.2\%) answered that the Student Ability Classification system was very good, 22 students (37.9\%) answered that the Student Ability Classification system was good, 2 students (3.4\%) answered that the Student Ability Classification system was less good, and 2 students (3.4\%) answered that the Student Ability Classification system was not good. The average respondent answers in a very good and good range.

Table 7.

The frequency variable of ATU criteria

\begin{tabular}{ccccc}
\hline No & Interval & Criteria & Frequency (f) & Percentage (\%) \\
\hline 1. & $9,75-12$ & Very good & 32 & $55,2 \%$ \\
\hline 2. & $7,49-9,74$ & Good & 22 & $37,9 \%$ \\
\hline 3. & $5,23-7,48$ & Less Good & 2 & $3,4 \%$ \\
\hline 4. & $3-5,22$ & Not Good & 2 & $3,4 \%$ \\
\hline & Total & & 58 & $100 \%$ \\
\hline
\end{tabular}

Table 8 shows that 58 students were the subjects of the study, 10 students (17.2\%) answered that the Classification Ability System of students was very intent on using the system, 43 students $(74.1 \%)$ answered that the system of Classification of Students' Ability to use the system, 4 students $(6.9 \%)$ answered that the Student Ability Classification system lacked the intention to use the system, and 1 student $(1.7 \%)$ answered that the Students' Classification Ability system was not intent on using the system. The average respondent answers in a range of intentions.

Table 8. The frequency variable of ITU criteria

\begin{tabular}{ccccc}
\hline No & Interval & Criteria & $\begin{array}{c}\text { Frequency } \\
(\mathbf{f})\end{array}$ & $\begin{array}{c}\text { Percentage } \\
(\mathbf{\%})\end{array}$ \\
\hline 1. & $14-16$ & $\begin{array}{c}\text { Very } \\
\text { Intention }\end{array}$ & 10 & $17,2 \%$ \\
\hline 2. & $11-13$ & Intention & 43 & $74,1 \%$ \\
\hline 3. & $8-10$ & $\begin{array}{c}\text { Lack of } \\
\text { Intention }\end{array}$ & 4 & $6,9 \%$ \\
\hline 4. & $4-7$ & $\begin{array}{c}\text { No } \\
\text { Intention }\end{array}$ & 1 & $1,7 \%$ \\
\hline & & 58 & $100 \%$ \\
\hline
\end{tabular}

Table 9 shows that 58 students were the subjects of the study, 7 students (12.1\%) answered that the Classification Ability System of students very often used the system, 41 students $(70.7 \%)$ answered that the System Classification Ability Students often use the system, 9 students (15.5\%) answered that the Ability Classification system of students rarely used the system, and 1 student $(1.7 \%)$ answered that the System of Classification of Abilities students very rarely used the system. The average respondent answers in a frequent range.

Table 9. The frequency variable of ASU criteria

\begin{tabular}{ccccc}
\hline No & Interval & Criteria & $\begin{array}{c}\text { Frequency } \\
(\mathbf{f})\end{array}$ & $\begin{array}{c}\text { Percentage } \\
(\boldsymbol{\%})\end{array}$ \\
\hline 1. & $14-16$ & $\begin{array}{c}\text { Very } \\
\text { Often }\end{array}$ & 7 & $12,1 \%$ \\
\hline 2. & $11-13$ & Often & 41 & $70,7 \%$ \\
\hline 3. & $8-10$ & Rarely & 9 & $15,5 \%$ \\
\hline 4. & $4-7$ & $\begin{array}{c}\text { Very } \\
\text { Rarely }\end{array}$ & 1 & $1,7 \%$ \\
\hline & & 58 & 100 \\
\hline
\end{tabular}




\subsection{Result of Teachers' Descriptive Analysis}

Table 10 shows the results of the TAM instrument by the teacher. From the results of TAM instruments by the teacher, the criteria for each variable will be categorized using formulas 1 and 2 . Based on formulas 1 and 2, the results of the calculation of PU variable criteria are shown in table 11. Table 11 shows that the Student Capability Classification system is very useful. It can be concluded that the Capability Classification System of Students has been felt useful by the teacher's.

Table 10. Result of TAM by Teacher

\begin{tabular}{ccccc}
\hline No & Variabel & Resp (N) & N & $\begin{array}{c}\text { Total } \\
\text { Respon }\end{array}$ \\
\hline 1. & PU & 1 & 6 & 22 \\
\hline 2. & PEOU & 1 & 8 & 32 \\
\hline 3. & ATU & 1 & 3 & 12 \\
\hline 4. & ITU & 1 & 4 & 16 \\
\hline 5. & ASU & 1 & 4 & 14 \\
\hline
\end{tabular}

Table 11. The frequency variable of PU criteria

\begin{tabular}{ccccc}
\hline No & Interval & Criteria & Frequency (f) & Percentage (\%) \\
\hline 1. & $19,5-24$ & Very Useful & 1 & $100 \%$ \\
\hline 2. & $14,9-19,4$ & Useful & 0 & $0 \%$ \\
\hline 3. & $10,3-14,8$ & Less Useful & 0 & $0 \%$ \\
\hline 4. & $6-10,2$ & Not Useful & 0 & $0 \%$ \\
\hline \multicolumn{2}{c}{ Total } & 1 & $100 \%$ \\
\hline
\end{tabular}

Table 12 shows that the Student Ability Classification system is very easy. It can be concluded that the ease of use of the Student Ability Classification System has been felt by the teacher.

Table 12. The frequency variable of PEOU criteria

\begin{tabular}{|c|c|c|c|c|}
\hline No & Interval & Criteria & $\begin{array}{l}\text { Frequency } \\
\text { (f) }\end{array}$ & $\begin{array}{c}\text { Percentage } \\
(\%)\end{array}$ \\
\hline 1. & $27-32$ & $\begin{array}{l}\text { Very } \\
\text { Easy }\end{array}$ & 1 & $100 \%$ \\
\hline 2. & $21-26$ & Easy & 0 & $0 \%$ \\
\hline 3. & $15-20$ & $\begin{array}{l}\text { Less } \\
\text { Easy }\end{array}$ & 0 & $0 \%$ \\
\hline 4. & $8-14$ & Not Easy & 0 & $0 \%$ \\
\hline & Total & & 1 & $100 \%$ \\
\hline
\end{tabular}

Table 13 shows that the Student Ability Classification system is very good. It can be concluded that the Student Ability Classification System is a good system.

Table 13. The frequency variable of ATU criteria

\begin{tabular}{ccccc}
\hline No & Interval & Criteria & Frequency (f) & Percentage (\%) \\
\hline 1. & $9,75-12$ & Very Good & 1 & $100 \%$ \\
\hline 2. & $7,49-9,74$ & Good & 0 & $0 \%$ \\
\hline 3. & $5,23-7,48$ & Less Good & 0 & $0 \%$ \\
\hline 4. & $3-5,22$ & Not Good & 0 & $0 \%$ \\
\hline & Total & 1 & $100 \%$ \\
\hline
\end{tabular}

Table 14 shows that users of the Classification Ability System students are very intent on using the system. It can be concluded that the teacher has intended to use the Student Ability Classification System. 
Table 14.

The frequency variable of ITU criteria

\begin{tabular}{ccccc}
\hline No & Interval & Criteria & $\begin{array}{c}\text { Frequency } \\
\text { (f) }\end{array}$ & $\begin{array}{c}\text { Percentage } \\
(\mathbf{\%})\end{array}$ \\
\hline 1. & $14-16$ & $\begin{array}{c}\text { Very } \\
\text { Intention }\end{array}$ & 1 & $100 \%$ \\
\hline 2. & $11-13$ & Intentiom & 0 & $0 \%$ \\
\hline 3. & $8-10$ & $\begin{array}{c}\text { Lack of } \\
\text { Intention }\end{array}$ & 0 & $0 \%$ \\
\hline 4. & $4-7$ & $\begin{array}{c}\text { No } \\
\text { Intention }\end{array}$ & 0 & $0 \%$ \\
\hline & & 1 & $100 \%$ \\
\hline
\end{tabular}

Table 15 shows that teacher as users of the Classification Ability System students, very often use the system. It can be concluded that the teacher has used the Student Ability Classification System to actually use the system.

Table 15. The frequency variable of ASU criteria

\begin{tabular}{|c|c|c|c|c|}
\hline No & Interval & Criteria & $\begin{array}{l}\text { Frequency } \\
\text { (f) }\end{array}$ & $\begin{array}{c}\text { Persentage } \\
(\%)\end{array}$ \\
\hline 1. & $14-16$ & $\begin{array}{l}\text { Very } \\
\text { Often }\end{array}$ & 1 & $100 \%$ \\
\hline 2. & $11-13$ & Often & 0 & $0 \%$ \\
\hline 3. & $8-10$ & Rarely & 0 & $0 \%$ \\
\hline 4. & $4-7$ & $\begin{array}{c}\text { Very } \\
\text { Rarely }\end{array}$ & 0 & $0 \%$ \\
\hline & Total & & 1 & $100 \%$ \\
\hline
\end{tabular}

\subsection{Result of Regression Analysis}

Testing the effect of each variable according to the TAM framework with regression analysis [4], [7]-[9]. The results of the regression analysis are shown in Table 16. Based on Table 16, it can be interpreted that the PU variable can be explained by the PEOU variable of $95.2 \%$ while the influence of $4.8 \%$ is caused by other variables outside of this model. So that it can be interpreted that the user's perception of the ease of use of the SATCS (PEOU) has a significant influence on the user's attitude about the usefulness of SATCS (PU). To test whether there is a relationship or not between PEOU variables and PU, a linear regression test is used. Decision making results of hypothesis testing, If $t$ count> $\mathrm{t}$ table then Ho is rejected and $\mathrm{Ha}$ is accepted. The linear regression test results are shown in Table 17.

Table 16. Independent Variable

\begin{tabular}{|c|c|c|c|c|c|}
\hline & & \multicolumn{4}{|c|}{ Independent Variable } \\
\hline & & PEOU PU & $A T U$ & $I T U$ & $A S U$ \\
\hline \multirow{5}{*}{ 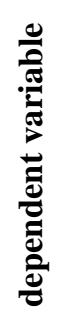 } & PEOU & & & & \\
\hline & $P U$ & $95.2 \%$ & & & \\
\hline & $A T U$ & $87.7 \%$ & & & \\
\hline & $I T U$ & & $3,9 \%$ & & \\
\hline & $A S U$ & & & $82.6 \%$ & \\
\hline
\end{tabular}


Table 17. Regression result of PEOU to PU

\begin{tabular}{cccc}
\hline Variabel & $\begin{array}{c}\text { Regression } \\
\text { Coefficient }\end{array}$ & $\mathbf{t}$ & Sig \\
\hline Constant & -2.633 & -3.934 & .000 \\
\hline PEOU & 0,841 & 33.349 & .000 \\
\hline
\end{tabular}

Table 17 shows that $t$ count is 33,349 . While the $t$ table is 2,003 . It can be concluded that the value of $t$ count $(33,349)>t$ table $(2,003)$, then Ho is rejected and Ha is accepted. So it was concluded that the Perceived Ease of Use had an effect on Perceived Usefulness.

Based on the TAM theory, perceived usefulness is also influenced by perceived ease of use because the easier a system is used, the system feels more useful. A sense of ease using technology / information systems will give rise to the feeling that the system has a function, and therefore creates a sense of comfort when working with technology / information systems [6], [9]. In addition, previous research has shown that if technology is easy to use, it will increase the interests of users to use technology [12]. So it can be concluded that there is a significant relationship between the ease of use of the system and the usefulness of the system.

Table 17 shows that the ATU variable can be explained by the PEOU variable and PU variable by $87.7 \%$ while the effect of $12.3 \%$ is due to other variables outside of this model. So that it can be interpreted that convenience and usefulness have a significant relationship with the willingness to use the system or in other words the more the system is easy to use and has high benefits, the feeling of users to use SATCS is also higher. To test there is a relationship or not between the variables PEOU and PU with ATU used multiple linear regression test.

Results of hypothesis testing, if $\mathrm{F}$ count $>\mathrm{F}$ table then Ho is rejected and $\mathrm{Ha}$ is accepted. The linear regression test results are shown in Table 18. Table 18 shows that $F$ count is 196,309 . While the $F$ table is 3.165. So that it can be concluded that the value of $F$ count $>F$ table $(196,309>3,165)$, then Ho is rejected and Ha is accepted. So it was concluded that Perceived Ease of Use and Perceived Usefulness together had an effect on Attitude toward Using (ATU). The attitude was strong enough in traditional TAM with the support of the influence of ease of use and usefulness [13]. So it can be concluded that there is a significant relationship between ease and usefulness of the system with the willingness or attitude of the user to use the system.

Table 18. Regression Result of PEOU and PU to ATU

\begin{tabular}{cccccc}
\hline Model & Sum of Squares & df & Mean Square & F & Sig \\
\hline Regression & 128.076 & 2 & 64.038 & 196.309 & $.000^{b}$ \\
\hline Residual & 17.941 & 55 & .326 & & \\
\hline Total & 146.017 & 57 & & & \\
\hline
\end{tabular}

Table 16 shows that the ITU variable can be explained by the PU variable and the ATU variable at $88.9 \%$ while the effect of $11.1 \%$ is due to other variables outside of this model. So that it can be interpreted that the user's perception of the usefulness of use (PU) and willingness to use (ATU) have a significant influence on the attitude of users about the interest in using SATCS (ITU) or in other words the higher the system benefits that will increase user interest using SATCS. To test whether there is a relationship or not between PU variables and ATU with ITU, multiple linear regression tests are used. Decision making results of hypothesis testing, if F count $>\mathrm{F}$ table then Ho is rejected and $\mathrm{Ha}$ is accepted. The linear regression test results are shown in Table 19.

Table 19. Regression result of PU and ATU to ITU

\begin{tabular}{cccccc}
\hline Model & Sum of Squares & df & Mean Square & F & Sig \\
\hline Regression & 131.454 & 2 & 65.727 & 220.093 & $.000^{b}$ \\
\hline Residual & 16.425 & 55 & .299 & & \\
\hline Total & 147.879 & 57 & & & \\
\hline
\end{tabular}


Table 19 shows that $\mathrm{F}$ count is 220,093 . While the $\mathrm{F}$ table is 3.165 . So it can be concluded that the value of F count> F table $(220,093>3,165)$, then Ho is rejected and $\mathrm{Ha}$ is accepted. So it was concluded that Perceived Usefulness (PU) and Attitude toward Using (ATU) together had an effect on Behavioral Intention to Use (ITU). Based on literature research, there is evidence that there is a relationship between attitudes and intentions in various contexts [14]. Behavioral intentions to use the system strongly related to use and behavioral intention were the main factors of user behavior while other factors influenced user behavior indirectly with behavioral intentions or attitudes [15], [16]. So it is clear that there is a relationship between usefulness or usability and willingness or attitude to use the system with the intention of the user to use the system. In other words there is a significant relationship between PU and ATU with ITU.

Table 16 shows that the ASU variable can be explained by ITU variables at $82.6 \%$ while the influence of $17.4 \%$ is caused by other variables outside of this model. So that it can be interpreted that the higher the interest of someone using the system will increase the actuality of system usage in their work. To test whether or not there is a relationship between ITU variables and ASU, a linear regression test is used. Decision making results of hypothesis testing, If $t$ count $>t$ table then Ho is rejected and Ha is accepted. The linear regression test results are shown in Table 20.

Table 20. Regression Result of ITU to ASU

\begin{tabular}{cccc}
\hline Variabel & $\begin{array}{c}\text { Regression } \\
\text { Coefficient }\end{array}$ & $\mathbf{t}$ & Sig \\
\hline Constant & 0,128 & .177 & .860 \\
\hline ITU & 0,942 & 16.331 & .000 \\
\hline
\end{tabular}

Table 20 shows that $t$ count is 16,331 . While the $t$ table is 2,003 . It can be concluded that the value of $t$ count $(16,331)>t$ table $(2,003)$, then Ho is rejected and Ha is accepted. So it was concluded that Behavioral Intention to Use (ITU) has an effect on Actual System Use (ASU) of actual behavior. In rational behavior theory, a person's behavioral intention will determine the actual performance of the actual behavior [17], [18]. So it can be concluded that the intention of the user to use the system has an effect on actual user behavior. In other words there is a significant relationship between ITU and ASU.

\section{Conclusion}

Based on the results and discussion, it can be concluded that the LVQ algorithm can be used to provide direction to classify the ability of students and choose a SCT package that matches the students' abilities for students even though it is not required to be implemented. Based on the results of the spread of the TAM instrument as an evaluation that focuses on the behavior of system users, the average respondent answers enough on each variable. So that it can be concluded on average users have felt the usefulness and ease of use of the system. The TAM variables also have a significant effect. So that each variable will influence the behavior of users of the system.

\section{References}

[1] Firdausa, A. P. Wibawa, and U. Pujianto, "Model Sistem Pendukung Keputusan Pemilihan Sekolah Menggunakan Metode Saw," Semnasteknomedia Online, vol. 4, no. 1, pp. 3-3-1, 2016.

[2] W. H. Pujianto, M. Hariadi, and S. Sumpeno, "Klasifikasi Berbasis LVQ Menggunakan Optimasi Learning Rate untuk Memilih Siswa Peserta OSN," Pros. Semin. Nas. Manaj. Teknol. XVII, pp. 1-7, 2013.

[3] Hartatik, "Data Manajemen dan Teknologi Informasi (DASI)," J. Ilm. DASI, vol. 16, no. 3, pp. 53-58, 2015.

[4] Y. Iriani, A. Mariana, S. Lestari, and Murnawan, "Analisis Penerimaan Sistem Informasi Berbasis Web Dengan Menggunakan Technology Acceptance Model,” Simp. Nas. RAPI XII, pp. 60-66, 2013.

[5] R. K. Chellappa and P. A. Pavlou, "Perceived information security, financial liability and consumer trust in electronic commerce transactions," Logist. Inf. Manag., vol. 15, no. 5/6, pp. 358-368, 2002. 
[6] F. D. Davis, "Perceived Usefulness, Perceived Ease of Use, and User Acceptance of Information Technology," MIS Q., vol. 13, no. 3, pp. 319-340, Sep. 1989.

[7] F. Fatmasari and M. Ariandi, "Penerapan Metode Technology Acceptance Model (TAM) Terhadap Penerimaan Krs Online (Studi Kasus : Mahasiswa Ilmu Komputer Universitas Bina Darma Palembang)," J. Matrik, vol. 16, no. 2, 2014.

[8] Z. Y. Liu, "An Analysis of Technology Acceptance Model- Exploring user acceptance and intension of taxi-hailing app in Shanghai," An Anal. Technol. Accept. Model, pp. 1-14, 2014.

[9] V. Wilson and U. Mbamba, "Acceptance of Mobile Phone Payments Systems in Tanzania : Technology Acceptance Model Approach,” Bus. Manag. Rev., vol. 2253, pp. 15-25, 2017.

[10] J. Munusamy, E. C. De Run, S. Chelliah, and S. Annamalah, "Journal of Internet Banking and Commerce," J. Internet Bank. Commer., vol. 17, no. 3, pp. 1-14, 2012.

[11] W. R. King and J. He, "A meta-analysis of the technology acceptance model," Inf. Manag., vol. 43, no. 6, pp. 740-755, 2006.

[12] C. S. Ong, J. Y. Lai, and Y. S. Wang, "Factors affecting engineers' acceptance of asynchronous e-learning systems in high-tech companies," Inf. Manag., vol. 41, no. 6, pp. 795-804, 2004.

[13] A. L. Lederer, D. J. Maupin, M. P. Sena, and Y. Zhuang, "The role of ease of use, usefulness and attitude in the prediction of World Wide Web usage," in Proceedings of the 1998 ACM SIGCPR conference on Computer personnel research, 1998, pp. 195-204.

[14]H. F. Lin, "Predicting consumer intentions to shop online: An empirical test of competing theories," Electron. Commer. Res. Appl., vol. 6, no. 4, pp. 433-442, 2007.

[15]F. D. Davis, R. P. Bagozzi, and P. R. Warshaw, "User acceptance of computer technology: a comparison of two theoretical models," Manage. Sci., vol. 35, no. 8, pp. 982-1003, 1989.

[16] Y. H. Lee, Y. C. Hsieh, and C. N. Hsu, "Adding innovation diffusion theory to the technology acceptance model: Supporting employees' intentions to use e-learning systems," J. Educ. Technol. Soc., vol. 14, no. 4, 2011.

[17]M. Fishbein and I. Ajzen, "Belief, Attitude, Intention, and Behavior: An Introduction to Theory and Research," Philos. Rhetor., vol. 10, no. 2, pp. 130-132, 1977.

[18]R. Greene, Human Behavior Theory and Social Work Practice, 2nd Editio. New York: Routledge, 2017. 